Veronika Planková

Copenhagen University, Denmark

\title{
FIGHTING THE (UN)HIDDEN “ENEMIES” OF THE SLOVAK SOCIETY
}

he development of the Slovak LGBTI community's rights has faced a backlash in the recent years. According to the "Rainbow Europe 2016” (ILGA-Europe 2016) report, Slovakia has achieved only 29\% of the overall score. Romana Schlesinger, a Slovak LGBTI activist and the executive director of the Queer Leaders Forum, characterised the situation as "the biggest backlash since the history of the Slovak Republic and the Velvet revolution" (personal communication, September 4, 2016). The backlash peaked in two key events - a change of the Slovak constitution \& the Referendum for the Slovak family.

In the 2014, two political parties united and agreed on an issue of strengthening the position of a marriage on the constitutional level. The change affected the Article 41 in which two sentences - "A marriage is a unique bond between a man and a woman. Slovak Republic protects marriage on all levels and help its goodness." (Ústava Slovenskej republiky 2015: 14, own translation) - were added. The proposal was drafted by the Christian-Democratic Movement $(\mathrm{KDH})$, specifically driven forward by the party leader Ján Figel' who believed that the implementation of this clause into the Slovak Constitution would protect family against external forces. $\mathrm{KDH}$ found an ally in the most represented party in the parliament, SMER- Social Democracy (SMER-SD). The proposed draft with the both its explanatory clauses and redefinition of the Article 41, was supported by 102 votes from $128 \mathrm{MP}$ present that day in the parliament.

The opposition criticised collaboration of these two parties. The Freedom $\&$ Solidarity party $(\mathrm{SaS})$ described the move as selfish and populistic: the "real meaning and motive is not a protection of a traditional family, but a culture of hate spread by the SMER-SD and KDH driven by pure self-interest." (TASR, 2014, para. 21, own translation) The reason for this might be the fact that Róbert Fico, the leader of the SMER-SD and the current Prime Minister, was 
running for the position of the Slovak president in the upcoming presidential elections of 2014. Nevertheless, Fico claimed that it would not "disturb", in his words: "the other people who have a different view on the issue, or who live differently." (TASR 2014, para. 12, own translation) As the law already defines the marriage as a bond between a man and a woman he perceived the constitutional upgrade of the law as harmless to those who he defined that time as "the other people".

However, there is an issue with the change which was meant to complicate the future for the same-sex couples in judiciary situations. It is at least what Ján Figel', the main person behind the change, have said in 2014. The purpose of the structure of the language and the draft is to limit the future possibilities of the same-sex couples to be recognised before the law. In his words:

...the proposition has its base, i.e. concrete proposition for the constitution's text; and explanation clause. In whatever situation, the explanation clause is always considered when it comes to the interpretation of this new change. [...] The constitutional definition will prevent any other partnerships to obtain the same credibility as marriage. That means, that the rights and duties of marriage won't be able to incur in other way than in legally binding connection between a man and a woman. Based on the changes in the constitution, marriage cannot and won't be able to incur between the same-sex individuals in Slovakia. (Obšitník 2014, para. 20, own translation)

Following the Figel's line of thought, there is a difference between the Article 41 of the Constitution and the Slovak Family Law Act of 2005 (2016) which defines marriage "as a bond between a man and a woman". (Art. 1, own translation) It is the word "unique" which occurs in the sentence added to the Constitution. The word "unique" has its special importance in the logic behind the formulation of the draft. Figel' explains it as follows:

The word 'unique' is that message for me, which means 'nothing else'. The word "unique" is clear in its definition [...] I would not sign a proposition without the words 'unique partnership.' The word 'unique' is so important for me that nothing else can describe this definition... (Obšitník 2014, para. 22, own translation)

The Explanation Clause is further trying to justify the above formulation of a marriage by what is defined here as a "natural family."

First of all, it refers to the family as the basic cell of the society. The clause understands the term "family" as a historical institution which precedes the 
state and guarantees its future existence. For this reason, many civilisations were condemned to self-destruction as they had not protected the status of family. (NRSR 2014) However, it is only the "natural" family formed by a marriage between a one man and one woman which can guarantee the survival of a nation. This formulation excludes not only the LGBTI families, but also one-parent or guardian type of families as being equally and fully recognised under the national law. When Figel' (2014) stated that "what is good for a family, is also good for the state," (TASR 2014, para. 17, own translation) he has limited the discourse about family only to the level of marriage as it is now defined by both the family law and the Constitution. The language of "naturalness" used in this type of discourse creates a notion of some kind of eternal status-quo which needs to stay untouchable as a symbol of stability. The external forces challenging it than are portrayed as revolutionary but in the negative meaning of destruction and chaos. As Benedict Anderson formulated in his book Imagined Communities (1983/2006): “. . in everything 'natural' there is always something unchosen. In this way, nation-ness is assimilated to skin-colour, gender, parentage and birth-era - all those things one cannot help." (143) Following Anderson, the LGBTI community is, therefore, excluded from natural-ness if the "true and healthy" nation(-ness) can only be represented and continued by a family scheme which is drafted in the above-mentioned way. Moreover, the draft highlights the negative influence of the external forces in the third paragraph of the explanation clause:

The development in the contemporary world and specifically in Europe shows the instability of a law when it comes to the definition and interpretation of these terms. This instability does not contribute in adequate protection of the family in the society. (NRSR 2014: 6, own translation)

The following paragraph mentions also other countries (Poland, Latvia, Hungary and Croatia) as good examples in the fight for the "natural character of the marriage and the family" (NRSR 2014: 6, own translation) which moved the definition of marriage as a bond between a man and a woman on the constitutional level.

Another important factor structuring the draft is its use of the international declarations. First of all, the second paragraph justifies the "natural family" as the best environment for a child. (NRSR 2014) It refers to the Article 3 of the United Nations Convention on the Rights of the Child (1989) which states in the part 1: 
In all actions concerning children, whether undertaken by public or private social welfare institutions, courts of law, administrative authorities or legislative bodies, the best interests of the child shall be a primary consideration. (p. 2)

The "best interest of a child" is the quoted part used in the explanation clause. As the natural family is the most adequate environment for both having and adopting children it supplements the restrictions for adoption by other forms of partnership or parenthood. Moreover, the discourse referring to the "best interest of a child" is a common part of other conservative campaigns as I will demonstrate in the later part of the paper.

Secondly, it is claimed in the Explanation Clause, that the definition of marriage stated by the clause is in accordance with other international human rights declarations. It specifically refers to the Article 16 of the Universal Declaration of Human Rights [UDHR] (The United Nations 1948); the Article 23 of the International Covenant on Civil and Political Rights [ICCPR] (The UN General Assembly 1966); and to the Article 12 of the European Convention of Human Rights [ECHR] (Council of Europe 1988) as examples of documents signed and respected by the Slovak Republic. In the Explanation Clause (NRSR 2014), the ninth paragraph is written as follows:

The International Declaration of Human Rights defines marriage as a legal bound between a man and a woman in the article 16. The equal characterisation of the institute of marriage as a bound between a man and a woman is shared also within other international declarations for human rights protection, by which the Slovak Republic is bind. (p. 7, own translation)

However, the statement is misleading. All the three declarations define marriage as an equal right for both men and women. They do not restrict the institution for heterosexual marriage right only, but protects it for every human being. For example, in the UDHR (UN 1948) it is written:

Men and women of full age, without any limitation due to race, nationality or religion, have the right to marry and to found a family. They are entitled to equal rights as to marriage, during marriage and at its dissolution. (Art. 16)

There are only two basic restrictions needed to be respected regarding legality of marriage - full consent and age. The ECHR is the only one which recognises the particularity of the "national laws governing the exercise of this right." (Council of Europe 1988, Art. 12) On the other hand, the ECHR omits 
a discourse about naturalness of family which is defined by the other two declarations as follows:

The family is the natural and fundamental group unit of society and is entitled to protection by society and the State. (UN 1948, part 3 of the Art. $16 \&$ UN General Assembly 1966, part 1 of Art. 23)

This statement both supports and contradicts the argument promoted in the Explanation Clause. While it follows the discourse about protecting family as the root of a society, the word "natural" is used differently in different meanings. As I already mentioned, the Explanation Clause is setting only one standard which it phrases as a "natural family" or a "natural bound" and protects it with defined "uniqueness of marriage". (NRSR 2014, own translation) All the other declarations are protecting the equality of rights of individuals in their claim for family and marriage. The only purpose of the "natural" and "fundamental" in the phrasing of the UDHR \& ICCPR is to state their inalienable right for full protection and support by the law, society and State. Later in 2013, the European Union even specified that the LGBTI persons are part of the category of mentioned protected individuals, and, although the ECHR does respect the national laws in the terms of marriage, the states should recognise that:

LGBTI persons have the same rights as all other individuals - no new human rights are created for them and none should be denied to them. The EU is committed to the principle of the universality of human rights and reaffirms that cultural, traditional or religious values cannot be invoked to justify any form of discrimination, including discrimination against LGBTI persons. (Council of the European Union 2013: 1)

Moreover, the Article 30 of the UDHR clearly prohibits any actors to strip other individuals of their basic human rights:

Nothing in this Declaration may be interpreted as implying for any State, group or person any right to engage in any activity or to perform any act aimed at the destruction of any of the rights and freedoms set forth herein. (UN 1948, Art. 30)

Therefore, while looking at Ján Figel's arguments we can observe that the logic of the proposed and accepted change follows a popular type of nationalist discourse in which he tries to stabilise the position of his party by forming an image of an enemy in a form of external force coming from the EU as mentioned in the third paragraph of the Explanation Clause (NRSR 2014). 
Figel"s argument lays in externalisation. While he sees marriage and family as discredited around Europe, he explains that a new dangerous "Gender Ideology" which has its origin in "the West" is trying to impose new moral values on other countries:

I see it as a growing influence of the "ethical relativism" which had many forms and outcomes in history. This time it is so-called "gender ideology" which - unlike the other ones - comes from unnatural understanding of human identity. [...] This is the beginning of chaos or beginning of new rights subverted from these outcomes. We don't accept them exactly because they mingle with every sphere and endangers the natural, universal and basic human rights. (Obšitník 2014, para. 7, own translation)

He understands the present situation as an attempt to violate basic human rights driven by lobbying forces. In that formulation, he appears as a protector of what he specified as "natural" human rights. (Obšitník 2014) What it is meant by "natural" was already explained in the above paragraphs. As he does not recognise the LGBTI persons (in this case homosexuals) being included in his pattern, they must, in his perception, create new rights for themselves. Although he said in the 2015 interview that he does see homosexuals as equal to him, he does not distinguish between their Human Rights and what he claims they are asking for, between the "special rights" (i.e. right to marry and to adopt children). This is a continuous and a common debate in the discourse concerning the LGBTI personages. Mostly the fundamental or conservative religious groups perceive the homosexual life as a sinful life-style and their bond, therefore, unnatural. For this reason, it is understandable that a party leader of a Slovak conservative Christian party might follow this line of thought. As the moral life of the gay and lesbian couples is, in his understanding, already corrupted it would be endangering to let them even adopt abandoned children. Moreover, allowing them to marry, or to let them equalise their partnerships on the level of marriage is a part of, what he described as, "salami tactics":

Firstly, there is a discussion about the change of perceiving relationships, then about partnership which wants the same rights as marriage and finally it influences the whole social sphere in a way that it is attacked by relativism and even ideology. (Kern 2015, para. 46, own translation)

Jana Dubovcová, the Slovak Public Defender of Rights, on the other hand, believes that a compromise should be made in this regard. She does not view the possibility of adoption for homosexual couples as an attack on the traditional 
family and affecting healthy upbringing of children. She sees it as a step which could be beneficial for the Slovak society in general as the rumours of the dangerous influence of homosexuals on children would be discredited:

Allowing this would only benefit our society. We would allow people to live following their own consciousness. Maybe, also the rumours about what an immoral life this part of society has would be confronted with the morals of those whose life is ordinary. This is, I believe, the way of the other European states which allowed this and that we certainly cannot portray them as morally corrupted or disrespectful towards the traditional values. (Jancová 2015, para. 7, own translation)

According to the law, "the adoption is considered only when the traditional family does not exist - either it failed, or the parents died and a child does not have anyone." (Jancová 2015, para. 9, own translation) When this kind of situation comes into being, the law should consider the best environment for a child, but "the Sexual orientation should not be the criteria for an applicant, but his/her capability to create a loving environment for a child.” (Jancová 2015, para. 10, own translation) Her comments refers directly to the Referendum for a Family which succeeded the above-discussed change of the Slovak Constitution, and which campaign was an open attempt against the LGBTI minority using, again, the children as the main subject of their claimed protection.

The Referendum About the Protection of Family was a massive call by the Alliance for Family, a civil movement which was establish in the 2013. It was held on the 7 th of February 2015 which was preceded by a petition. The Alliance managed to collect more than 350 thousand signatures which is the minimum requirement for the validation of the petition by the President. The focus on children was the main driving force behind the campaign, which I believe as part of the started Constitutional change in 2014, was an attack on the LGBTI community presenting it as an external force destabilising the moral order of the country.

The external force is in this case the European Union. However, it is clearly portrayed more negatively than in the Explanatory Clause of the discussed draft. The content of the petition collects all the aspects of this message and shows the fear of the "Salami tactics" mentioned by Jan Figel' before:

Abandon children also deserve to have mom and dad, and, because of that, we need to insist on that the best interest of children must be a priority during adoption, not the interest of adults. [...] Children are naturally born and raised only in a relationship consisting of a man and a woman. For this reason, the same-sex couples or groups 
cannot make a claim for the same rights as marriage has. We vote for keeping the present order. Approving the registered partnerships would lead to a situation when the European courts would grant them, even without our permission, all the rights which only marriage has in our country. (Alliance for Family 2014, March 1, own translation, original highlights)

According to the Slovak Law Act about the organisational manner of conducting a referendum (2015, own translation), it is the President's duty to control whether the petition is in accordance with the constitution. The current Slovak president Andrej Kiska followed this duty and before announcing the referendum, he sent it to the Constitutional Court to analyse the content of the questions. There were originally four referendum questions:

1. Do you agree that no other cohabitation but the union between one man and one woman should be called marriage?

2. Do you agree that neither same sex couples nor groups shall be allowed to adopt children and subsequently raise them?

3. Do you agree that to no cohabitation of persons, except marriage, should be granted special protection, rights and obligations, which have been granted by legislative acts up to 1.3.2014 only to marriage and spouses (in particular the recognition, registration as a lifelong union before the public authority, the possibility of adopting a child by the parent's other spouse).

4. Do you agree that schools cannot require the participation of children in classes dedicated to sexual behaviour or euthanasia if their parents or the children themselves do not agree with the content of the lessons? (Alliance for Family n. d.)

The third question was considered as unconstitutional and excluded from the referendum sheet by The Slovak Constitutional Court. The other three questions were approved and referendum was announced to take place in February 7, 2015.

The decision of the court was viewed as a failure by many critics. The Slovak Constitution (2014) states clearly in the Article 93 section 3, that "No issues of fundamental rights, freedoms, taxes, duties or state budget may be decided by a referendum." As the Constitutional Court had not recognised the first and the second questions as interconnected and aimed against the rights of the LGBTI minority, and, therefore, unconstitutional, it supported the future discrimination of this group. The Amnesty International made a similar 
statement. It had seen the referendum as a backward step for Slovakia which would show how Slovakia really perceive what the Human Rights are and who has the right for them. In the words of Jana Malovičová, the director of the Slovak branch of the Amnesty International (2015a): "It is a decision about whether we believe that everyone has the same rights for a family and for the protection of the Human Rights." (para. 3, own translation) Although AZR officially stated that their campaign was not meant as an attack against "ordinary homosexual couples" (STV 2015), or, that they are "not bound to any ideology, religion or political party", (AZR n. d.) the content of their official page (besides the referendum questions) gives a different impression. For instance, an article presented as Endangerment of Family in the World and in Slovakia, (AZR 2014, April 5) mentions 32 examples of situations which are supposed to threaten the status and the healthy well-being of a family in the world and in Slovakia. From this number, the content of 18 out of 22 in the world and 5 out of 10 in Slovakia are aimed against the same-sex marriages, registered partnerships and adoptions. Moreover, in the part called "Why is the referendum important?" (AZR n. d.) the following was written:

There are big pressures from western countries and the European Union bodies to redefine marriage and family, also in Slovakia. These countries and bodies already accepted the ideology of 'marriage for all', in many cases denying freedom of speech and conscientious objection. Also, our state institutions are already filled with pro-gay activists and thus it is hard to resist the pressure. Most politicians are scared of resisting the pressure from EU, too.

In the other sections of their page, the AZR explains the purpose of every referendum question.

Beginning with the first question, a marriage is perceived similarly as in the Explanatory Clause discussed earlier in the paper. Marriage is connected to the core of the state as it ensures the continuity of the nation. It mentions that if homosexuals' partnerships were equalised with marriage (by the EU courts for example), nothing would ban them to have the "same rights or services" (AZR 2016b, April 21, own translation) as marriage is legally allowed to have.

The second question deals more or less with who has a right for children. It refers to children as to have mother and father is their basic rights to have and the state needs to consider this option before any other. This is already the main concern of adoption policies as Jana Dubovcová already pointed out. Furthermore, it implies that for the reasons of healthy upbringing, a child needs to 
experience "examples both a man and a woman, their mutual love, respect and coexistence." (AZR 2016a, April 21, para. 2, own translation) Mentioning example of Austria, it warns against "activist interventions of the European Court for Human Rights" which prioritise the "so-called principle of 'non-discrimination' instead of the principle that a child needs a father and a mother." (AZR 2016a, April 21, para. 3, own translation) This is again the case of hijacking the topic of human rights for an own cause.

The longest explanation was added to the third question originally banned by the Slovak Constitutional Court. The reference to the Explanation Clause of the 2014 is clear. The explanation offered here backs marriage's claimed uniqueness and the importance of protecting this uniqueness for the future generations. The "salami tactics" of adoption rights is an unavoidable danger if the registered partnerships would be allowed. The Alliance highlights that this might be the last opportunity to "ban 'values' forced from outside", (AZR 2016c, para. 5, own translation) because if the registered partnerships were allowed, the European Union would be unstoppable in imposing these values on the Slovak society while banning the right to object. This sort of discourse fortifies the illusion that the European Union is a type of dictatorship which would consume the identity of the separate nations if they let it infiltrate their structure.

The battlefield here is on the ground of Human Rights which are designed to guarantee rights of every individual. The organisations or activists representing the LGBTI group are described here as "lobbyists" who "are going far behind the border of non-discrimination; and actually, discriminate and have potential to corrupt the correct understanding of the root and purpose of marriage and family." (AZR 2016c, para. 4, own translation) In this formulation, the Alliance is trying to portray itself as not truly rallying against homosexuals, but only against those lobbyists who are trying to legalise what Alliance believes are the special rights. In an interview with a homosexual couple conducted by the Dennik N, Roman, one of the partners, described the following double-standard towards discrimination with words: "It is different to be truly discriminated and feel discriminated for to not be allowed to discriminate others." (Mikušovič 2015, para. 57, own translation) Alliance also claims that rights for inheritance and health state of a partner could be easily achieved through other legal institutions and so they do not need to be legally recognised as partnership union.

The last question also demonised the foreign influence. While calling it "ideological exercises" (AZR 2016d, para. 6, own translation) on children 
which parents should have a right to refuse, it defined two basic types of sexual education - "An Education towards responsible sexual behaviour and parenthood" (AZR 2016d, para. 3, own translation) and "permissive sexual education." (AZR 2016d, para. 4, own translation) The former is described as the correct one which mainly encourages young adults into responsibility and sexual abstention before marriage. The latter is described as opposite, and dangerous (according to the Alliance believes) following the concept of "safe sex - the usage of condoms and hormonal anticonception for averting pregnancy while accepting artificial abortion as a solution for unplanned pregnancy." (AZR 2016d, para. 3, own translation) The Alliance claims that this latter type of sexual education which is adored in the western countries lead to grow in number of abortions, early pregnancies and sexual diseases. They do not support their claim with any statistical evidence. What they mention as a proof for their concerns is an example coming from Germany where children cannot skip any subject nor sexual education class if the objection is based on their religion. The reason for this is to offer children a neutral ground apart from the parents' values to offer them an opportunity to choose by themselves (Houlton 2009). Nevertheless, the other sources of influence on the existence of the forth question are, I believe, the two broadly discussed EU reports drafted in 2013 and 2014 - Estrela \& Lunacek Reports.

Both reports, despite being non-binding to the states, were criticised and attacked by conservative (and) religious groups. The former called The Report on Sexual and Reproductive Health and Rights (Committee on Women's Rights and Gender Equality 2013) authored by Edite Estrela, a Portuguese MEP, was a reaction to results of The Gender Inequality Index (The United Nations 2015) which is monitoring dimensions of health, empowerment and labour market. The suggestions provided in the report were supposed to enhance the quality and equality in terms of health care services; or to help to reform or establish a quality sexual education at schools which would lower the rate of unwanted pregnancies and provide information for youth to lead safe and responsible sex life. The data collected focused on, for example, "forced or coerced sterilisation", "Maternal Mortality", "Abortions", "Adolescent Birth Rates and Unwanted Pregnancy", "Sexually Transmitted Infections", economic difficulties for fresh parents, Gender-based violence or the continuous discrimination of LGBTI and their sexual and reproductive rights. (CWRGE 2013) The criticism of the report's data was mainly concerned about abortions together with the conscientious objection of doctors, contraceptions, sexual education and LGBTI parenthood. For instance, 
the Article 43 (CWRGE 2013) of the report highlights the importance of distinguishing the difference between the sexual and reproductive health needs of adults and adolescents. It "calls on the Member States to ensure that adolescents have access to user-friendly services where their concerns and rights to confidentiality and privacy are duly taken into account." (p. 13) This point is incorrectly presented, for example, by the Federation of Catholic Family Associations in Europe (FAFCE) as forcing the states to make "sex education classes compulsory for all primary and secondary school children" (FAFCE 2013, para. 21) in which the education for children aged 0-4 would "give information about enjoyment and pleasure when touching one's body, early childhood masturbation'; 'Enable children to gain an awareness of gender identity and give the right to explore gender identities". (FAFCE 2013, para. 23) It is important to mention this as the anti-report campaign significantly influenced the rejection by the European Parliament (334 to 327) (Honor 2013).

The latter Lunacek report, on the other hand, passed. The Report on the EU Roadmap Against Homophobia and Discrimination on Grounds of Sexual Orientation and Gender Identity (CCLJHA 2014) authored by Ulrike Lunacek, an Austrian MEP, was backed by the EU Parliament with 394 members in favour. Lunacek's mail service was later spammed by negative anti-report emails as before happened to Estrela as well. Moreover, her personal website was hacked with a banner warning against a harming content to the reader's computer (Nielsen 2014). Conservative campaigns against the report were also mobilised, as for example, on the Citizen Go page which is a well-known representative of conservative religious and anti-LGBTI groups or pro-life supporters. It firstly, highlights the victory over the Estrela report and the need to mobilise, again, against the new danger which comes now from the "LGBT activists to twist what is meant by fundamental human rights." (Citizen Go Europe 2014, para. 3) Lunacek herself is described as a "left-wing feminist" who by her showed support towards the Estrela report before advocated "taboo-free and interactive sex education for toddlers." (Citizen Go Europe 2014, para. 5) The LGBTI group is again portrayed as advocating for special treatment or the so-called "special rights" turning their campaigns for recognising their right for human rights as lobbying attempt to be awarded "special privileges." (Citizen Go Europe 2014, para. 6) Their campaigns are described as "institutional queering of human rights" which would force Member States to "engage in a holistic homosexual mainstreaming of all public policy domains" (Citizen Go Europe, 2014, para. 7) which would, for example, pressure "Member States to provide legal recogni- 
tion of same-sex 'marriages."' (Citizen Go Europe 2014 para. 8) Although the language, misinterpretation, and hysteria on the Citizen Go page (or by other groups) is more rigid in formulation than the information on the Alliance for the Family page, the similarity of the arguments and the fears following both reports are obvious.

The Catholic Church had its own specific involvement in the campaign. The most influential and also shocking was The Pastoral Letter of Slovak Bishops Regarding the National Referendum About the Protection of Family (Katolícka Cirkev na Slovensku 2015, own translation) which was transferred from the Synod of Bishops in Slovakia and presented in all churches, only 5 days before the Referendum. Martin Macko described it as "the first time the Church has been involved in a political issue in such an extent." (Minarechová 2015, para. 5) In the letter, they referred to the speech of the Pope John Paul II. (1996), dedicated to the Slovak pilgrims on the 9th November 1996 where he addressed Slovakiàs specific role in defining the new trend of the Third Millennium. The devotion to the Holy Virgin, the traditions, culture, martyrs and freshly raised generations, is the gift which the Slovak Catholics can offer to Europe and help it in its delicate moment.

The letter was highly criticised for its content. Homosexuality was portrayed as a behaviour which children would be pushed into by some dangerous ideologies from outside. As children are the future for everyone in the society, the letter highlights the importance of the type of family they should grow up in. Therefore, children must not be, as the letter describes, "demoralised since childhood." (KCS 2015, para. 1, own translation) The demoralisation is hidden in the questions about the life, family and sexuality, which took nearly a "sinister" form in many European countries. The examples enclosed in the letter, are euthanasia, sexual education, homosexuality and conscientious objection of doctors. All these are claimed to be parts of the "Gender Ideology" which the letter defines as "non-scientific ideological argument that two-typed gender - masculine and feminine - does not actually exists." (KCS 2015, para. 2, own translation) The parents and grandparents should not be passive and careless and not let the other forces to deform the "identity and sexuality" of their children and grandchildren. The letter says that the Alliance for Family offered a way to fight the danger with the referendum describes as peoples' "basic human right for opinion.” (KCS 2015, para. 6, own translation) Similar to Figel's logic, it does not see the referendum as violating the Human Rights of others. Although it mentions that this and other criticism was raised regarding the referendum, it views it only as an effort to demotivate people to vote. 
The "people", however, is a category which does not include everyone holding the Slovak citizenship. The discourse of endangered "us" creates a notion of imagined coherent community (Anderson 1983/2006) which represents the "true" Slovak identity threatened now by a foreign ideology. As the urgent tone of the letter suggests, the "we" or "us" are the chosen one who must take an action, gather as many people who share the same values and vote to save the "young lives and families. [...] Not every generation gets a chance to decide about the future of its homeland; we are facing a challenge to express our opinion about the fundamental life values. [...] Our whole society is built on them, but falls apart without them.” (KCS 2015, para. 10, own translation)

The last part of the letter focuses on the Pope Francis. The campaign of the referendum was criticised for hijacking the current Pope words for their campaign. Although Pope Francis (2015) showed support for the "courageous Slovak Church, which at this moment, at this time, is fighting to defend the family. Continue with courage!"; but he never commented only on the referendum directly and never expressed support for its questions. Pope's words are extracted from different homilies and speeches and organised in the letter to support every of the questions. Some parts are extracted from the time before he was being elected for the Pope in 2013. The eight paragraph refers to his time as Cardinal Bergoglio and to his letter protesting against the same-sex marriage from the June 2010:

The life of so many children who will be discriminated beforehand due to the lack of human maturity that God willed them to have with a father and a mother is in jeopardy. A clear rejection of the law of God, engraved in our hearts, is in jeopardy. [...] Let us not be naive: it is not a simple political struggle; it is an intention [which is] destructive of the plan of God. [...] a "move" of the father of lies who wishes to confuse and deceive the children of God. (para. 2-3)

The Pope has certainly been critical to the above-mentioned understanding of the so-called "Gender Theory" and he has showed support in the fight against it. In an interview in 2015 he defined it as an "Ideological Colonization" in which an idea is introduced "to the people that has nothing to do with the people. With groups of people yes, but not with the people. And they colonize the people with an idea which changes, or means to change, a mentality or a structure. [...] through the children." (Kara 2015, para. 9)

This statement partly explains the origin of the fourth question of the referendum and the fear about the sexual education reforms in schools. Moreover, 
it also supports the creation of the discourse about "us" and "them", about the values of claimed majority threatened by minority which values put it on the border of being recognised as an equal part of the society.

The Catholic Church has not been perceived by the general population as inclining to extremism. It is at least what the Slovak police report on extremism (MVSR 2012) showed in the 2012. The questioned participants did not see the Church as contributing to the recognised problem of growing popularity of the extremist groups. Although the low turnout on the referendum (21.4\%) and so its rejection was perceived as a positive step towards LGBTI rights, by NGOs such as Amnesty International (2015b) some argue that the turnout was low simply because it was perceived as unimportant and as a waste of money. On the other hand, I believe that it had influenced the election turnout for the $K D H$ party which lost its position in the parliamentary elections (from $8.82 \%$ in 2012 to $4.94 \%$ ) in 2016. However, it opened a door for other conservative parties, such as the Slovak National Party (8.69\%) and the controversial We are Family Party (6.62\%) (ŠÚSR 2016). The representative of the Slovak National Party, Andrej Danko, now a chairman of the National Council, recently assured the religious representatives that he would always support the Christian values and reject any attempts of LGBTI group to establish their rights (SITA 2016).

The most disturbing outcome of the elections is the victory of the neo-fascist Kotleba Peoples Party - Our Slovakia (8.04\%) (ŠÚSR 2016). Its leader, Marián Kotleba, who has a long history of extremism, was also elected as a governor of Banská Bystrica region in the 2013. On the one hand, he does not differ from many other right-wing conservative parties in the EU now. His campaigns are strongly nationalistic, euro-sceptic, Islamophobic, anti-refugees and anti-LGBTI. On the other hand, the devotion to the WWII Slovak State connects him specifically to the history of the fascist Catholic Slovak Church of that time. His party openly admires the president of the WWII Slovak State, Jozef Tiso, who as a catholic priest collaborated with Hitler. Moreover, the national literature in time of defining both the language and the sense of being a Slovak was mainly formed by the catholic or protestant priests in the $18^{\text {th }}$ and $19^{\text {th }}$ century. There is, therefore, a direct connection between the nationalist discourses and religion in Slovakia. The values supported and spread in (or pretending to be with) accordance with Christianity are presented by nationalists as the core values of the Slovak society.

Unfortunately, this logic naturally transfers the situation of the LGBTI group from into exclusion by the national community. The identity of any person is influenced by the society he/she lives in. If the LGBTI group continues 
to be excluded, their self-identification could be reshaped into seeking refuge in some closed and secure groups which would mean stronger feelings of exclusion. This relates to the Charles Taylor's (1994) discussion about recognition and Anthony Appiah's concept about the positive and negative life-scripts which are relevant in this time as the LGBTI community is asking for its voice and recognition. Kwame Anthony Appiah (1994) states that in a society where the negative scripts are influencing and shaping the identity of a certain minority groups, some "rights" equalising their position are not enough to preserve and restore their dignity. Focusing on homosexuals, even a life "as an 'open homosexual' cannot be enough. It will not even be satisfactory to be treated with equal dignity despite being homosexual, for that will require a concession that being a homosexual count naturally or to some degree against one's dignity. And so, one will end up asking to be respected as a homosexual.” (Appiah 1994: 149).

The collective identity is than strengthened and reshaped. This might be perceived as an oppressive action towards the rights of the majority. However, as these two groups are strictly interconnected, nationalism can hijack a sensitive issue of this measure and turn the majority away from the mutual discussion with the minority. It can than misuse the LGBTI need for recognition for a purpose to strengthen collective identity of the majority group in a form of emotional blackmailing. As it was discussed in this paper, it can emphasise the difference in the basic structure of the family on its moral and legal level. On the one hand, the impossibility of a "natural" reproduction for homosexual couples and the "traditionalism" behind marriage turns to be an argument against gay marriage on the level of law, because cohabitation of the same-sex couples cannot fulfil the need for survival of a nation. On the other hand, the problem with recognising LGBTI persons as normal and their sexuality as natural (as many studies concluded) turns the conflict into a fight for a moral purification of the society and into the discourse relating to the protection of children. In this sense, nationalism hijacks the children as they are the future for the new generations and the means of how the nation would identify itself in the future. In this understanding, their "healthy" upbringing, therefore needs protection. Of course, the healthy upbringing is only possible in the traditional family with possibility to control the sexual education in order to prevent them to have any homosexual "tendencies" as these conservative groups tends to say.

This "struggle" is shifted to the European Union's ground. As discussed in the paper, the "western countries" already implemented or are trying to implement measurements to recognise LGBTI people within its borders. This equal- 
isation of the LGBTI rights seems to add, as I tried to demonstrate, a new vocabulary for the mentioned homophobic groups on the level of language of Fundamental Human Rights. These groups do not recognise this act as a process of equalisation but as a process of making important exceptions to the rule where the LGBTI group claims to have "special rights."

\section{References}

Aliancia za rodinu [Alliance for Family, AZR] (n. d.). The Referendum for the Protection of Family in Slovakia, Alliance for the Family. Retrieved from: http://www.alianciazarodinu.sk/english/

Amnesty International, Áno v referende podporí diskrimináciu a zakonzervuje krajinu v prijimani dallsej legislativy [Yes in Referendum Would Support the Discrimination and Conserves the Country's Capability in Adopting a Different Legislation], 4 February 2015a. Retrieved from: http://www.amnesty.sk/

Amnesty International, Neúspešné referendum je krokom smerom $k$ prijatiu novej legislativy $v$ tejto oblasti [The Failed Referendum is a Step Forward Towards a New Legislation in This Field], 8 February 2015b. Retrieved from: http://www.amnesty.sk/

Anderson, B., Imagined Communities. London, New York: Verso, 2006 (original work published 1983).

Appiah, K. A., "Identity, Authenticity, Survival: Multicultural Societies and Social Reproduction," in: Gutman, A. (ed.). Multiculturalism: Examining the Politics of Recognition, New Jersey: Princeton University Press, 1994, 149-163.

AZR, Petícia prezidentovi Slovenskej republiky za vyblásenie referenda [Petition for Holding a Referendum Addressed to the President of the Slovak Republic], 1 March 2014. Retrieved from: http://www.alianciazarodinu.sk/

AZR, Ohrozenia rodiny vo svete a na Slovensku [Endangerment of Family in the World and in Slovakia], 5 April 2014. Retrieved from: www.alianciazarodinu.sk/

AZR, Adopcia [Adoption], 21 April 2016a. Retrieved from: http://www.alianciazarodinu.sk/

AZR, Manželstvo [Marriage], 21 April 2016b. Retrieved from: http://www.alianciazarodinu.sk/

AZR, Registrované partnerstvá [Registered Partnerships], 21 April 2016c. Retrieved from: http://www.alianciazarodinu.sk/

AZR, Sexuálna výchova a eutanázia [Sexual Education and Euthanasia], 21 April 2016d. Retrieved from: http://www.alianciazarodinu.sk/

AZR, Je referendum NUTNÉ? [Is the Referendum Necessary?], 21 April 2016e. Retrieved from: http://www.alianciazarodinu.sk/

Cardinal Bergoglio, May the Holy Family join us "in God's War". Rorate Caeli, 22 June 2010. Retrieved from: http://rorate-caeli.blogspot.com/

Citizen Go Europe. EU-Parliament to vote on a Roadmap for special LGBT rights: \#LunacekNO, 16 January 2014 (Online Petition). Retrieved from: http://citizengo.org/en/ 
Committee on Civil Liberties, Justice and Home Affairs [CCLJHA], 7 January 2014. Report on the EU Roadmap against homophobia and discrimination on grounds. The European Union. Retrieved from: http://www.europarl.europa.eu

Committee on Women's Rights and Gender Equality [CWRGE], 2 December 2013. Report on Sexual and Reproductive Health and Rights. The European Union. Retrieved from: http://www.europarl.europa.eu

Council of Europe, Protocol to the Convention for the Protection of Human Rights and Fundamental Freedoms (European Convention on Human Rights) as amended by Protocol No. 11. Council of Europe Treaty Series 155. Strasbourg: Council of Europe, 1988.

Council of the European Union, Guidelines to promote and protect the enjoyment of all human rights by lesbian, gay, bisexual, transgender, and intersex (LGBTI) persons. The European Union, 24 June 2013. Retrieved from: http://www.consilium.europa.eu/en/home/

Federation of Catholic Family Associations in Europe [FAFCE]. 12 Reasons to Vote Against the Estrela Resolution on Sexual and Reproductive Health and Rights. FAFCE, 18 October 2013. Retrieved from: http://www.fafce.org/

Houlton, S., German Court Rules Sex Education Classes Not Optional. Deutsche Welle, 7 August 2009. Retrieved from: http://www.dw.com/

ILGA-Europe, Annual Review of the Human Rights Situation of Lesbian, Gay, Bisexual, Trans and Intersex People in Europe, 2016. Retrieved from: http:/www.ilga-europe.org/

Jancová, D., Dubovcová: Dovol'me žit lud’om slobodne [Dubovcová: Let's Let People Live Freely]. Verejný ochranca práv, 23 January 2015. Retrieved from: http://www.vop.gov.sk/

Kara, D., In-Flight Press Conference of His Holiness Pope Francis from the Philippines to Rome. Libreria Editrice Vaticana, 19 January 2015. Retrieved from: https://w2.vatican.va/

Katolícka Cirkev na Slovensku [KCS], Pastiersky list biskupov Slovenska k národnému referendu o ochrane rodiny dña 7. februára 2015 [The Pastoral Letter of Slovak Bishops Regarding the National Referendum About the Protection of Family], 1 February 2015. Retrieved from: https:/www.kbs.sk/

Kern, M., "Figel: Homosexuáli sú plnohodnotní ludia, no ich manželstvo odmietam” [Figel': Homosexuals are Fully Valued People, but I Reject Their Marriage], Dennik N, 16 January 2015. Retrieved from: https://dennikn.sk/

Mahony, H., Parliament Fails to Pass Report on Women's Rreproductive Rights. EU Observer, 10 December 2013. Retrieved from: https://euobserver.com/

Mikušovič, D., Tradičná rodina a homosexuálny pár. Spája ich tango, strávili sme s nimi nedelu [Traditional Family and a Homosexual Couple. They Share Tango, We Shared Sunday with Them], 6 February 2015. Retrieved from: https://dennikn.sk/

Minarechová, R., LGBTI Advocate Addresses Referendum. The Slovak Spectator, 26 January 2015. Retrieved from: http://spectator.sme.sk/

Ministerstvo vnútra Slovenskej Republiky [MVSR], Príciny rastu radikalizácie a agresivity určitých skupin obyvatelstva [The Causes of Growing Radicalisation and Aggression of Certain Groups of Population], 2012. Retrieved from: http://www.minv.sk/

Národná rada Slovenskej Republiky [The National Council of the Slovak Republic, NRSR], Návrh poslancov NRSR Jána Figela na vydanie uistavného zákona, ktorým sa mení a doplina Ústava Slovenskej republiky č. 460/1992 Zb. v zneni neskoršich predpisov, 24 February 
2014. Retrieved from: http://www.nrsr.sk/

Nielsen, N., MEP Receives 41,000 Emails Against Gay Rights. EU Observer, 4 February 2014. Retrieved from: https://euobserver.com/

Obšitník, L., J. Figel: Manželstvo je spochybňované po celej Európe, kritika jeho ukotvenia je falošná [J. Figel: The Status of Marriage is Degraded Around the Whole Europe. The Criticism of its Roots is False]. Denník Postoj, 20 March 2014. Retrieved from: https://www.postoj.sk/

Pope, F., Morning Meditation in The Chapel of the Domus Sanctae Marthae. He who intercedes on our behalf. Libreria Editrice Vaticana, 22 January 2015. Retrieved from: https:// w2.vatican.val

Pope John Paul II, Discorso Di Giovanni Paolo II Ai Pelegrini Slovacchi Riuniti Nella Basilica Vaticana. Libreria Editrice Vaticana, 9 November 1996. Retrieved from: https:// w2.vatican.va/

SITA, Danko vystúpil proti LGBTI. Urobi všetko, aby sa ich práva nepresadzovali [Danko Stood Against LGBTI. He Will Do Everything to Ban Them Pursuing Their Rights]. 8 September 2016. Retrieved from: http://domov.sme.sk/

STV, O 5 minút 12 [5 minutes to 12]. RTVS, 1 February 2015. Retrieved from: http:// www.rtvs.sk/televizia/archiv/7707/57885

Štatistický úrad Slovenskej republiky [ŠÚSR], Volby do národnej rady SR 2016. [Election of the National Council of Slovak Republic], 2016. Retrieved from: http://www.volbysr. sk/sk/data02.html

TASR, Poslanci zmenili ústavu a povýsili manželstvo. [The Ministers Changed the Constitution and Upgraded the Status of Marriage]. Teraz, 4 June 2014. Retrieved from: http:// www.teraz.sk/

Taylor, Ch., "The politics of Recognition (extracts)," in: Gutman, A. (ed.). Multiculturalism: Examining the Politics of Recognition, New Jersey: Princeton University Press, 1994, $25-73$.

The Constitution of the Slovak Republic, 2014. Retrieved from: https:/www.prezident.sk/ The United Nations, 1948, Universal Declaration of Human Rights.

The United Nations, 1989, Convention on the Rights of the Child. Treaty Series, 1577, 3.

The United Nations, Human Development Reports: Gender Inequality Index, 2015. Retrieved from: http://hdr.undp.org/en/content/gender-inequality-index-gii

The United Nations General Assembly, 1966, International Covenant on Civil and Political Rights. Treaty Series, 999, 171.

Ústava Slovenskej republiky [Constitution of the Slovak Republic], 2015. Retrieved from: http://www.nrsr.sk/

Zahradníková, J., Manželstvo ako jedinečný zväzok muža a ženz v ústave SR [Marriage as a Unique Bond Between a Man and a Woman, in Constitution of SR], 10 August 2015. Retrieved from: http://zahradnikova.sk/legislativa/manzelstvo-ako-jedinecnyzvazok-muza-a-zeny-v-ustave-sr/

Zákon o rodine [Family Law Act] of 2005, 36 Law Codex of the Slovak Republic, 2016.

Zákon o spôsobe vykonania referenda [The Law Act about the means of conducting a referendum] of 1992, 564 Law Codex of the Slovak Republic, 2015. 